\title{
ANALISIS PRAKIRAAN PRODUKSI DAN KONSUMSI BERAS INDONESIA
}

\author{
Apri Andani \\ Jurusan Sosial Ekonomi Pertanian Fakultas Pertanian Universitas Bengkulu
}

\begin{abstract}
The provisions of food in order to fullfil the humankind needs could be examined through the implementation of the process of agriculture production. However the requirement for food could only be fulfilled self-sufficiently if food supplies were higher than the total consumption. An increasingly descended trend of the increase of the Indonesian rice production was the problem that immediately must be overcome. This was caused by continously consumption growth resulting from the population growth. The aim of the research is to forecast the Indonesian Production and Rice Consumption, to estimate the supply capacity of domestic food (not including the import) compared with consumption of food nationally. To answer this aim, then it was carried out by the analysis of the forecast by using the method of Box-Jenkins with the model of ARIMA.

The forecast result showed that the production of rice rise every year since the year of 2008-2012. The rise in general as big as 700 thousand ton per year is caused by the increase of the harvesting area as well as the land productivity. On the other hand, national rice consumption in aggregate also increased as big as 450 thousand ton every year. In 2012, consumption of the national rice is estimated tol reach more than 33 million ton. The continuing population growth results in increasing rice consumption per capita, but it shows a declined sign every year from 134 $\mathrm{kg} /$ capita in 2005 to only $130 \mathrm{~kg} / \mathrm{capita}$ in 2012. However, this result doesnot give any impact anything on total consumption.
\end{abstract}

Keyword: forecast, ARIMA, rice, production, and consumption

\section{PENDAHULUAN}

Hasil penelitian Darwanto dan Prima (2007) mengemukakan bahwa dalam empat dekade terakhir produksi beras nasional telah mampu memenuhi sekitar $97 \%$ dari total pasokan yang dibutuhkan setiap tahun. Pasokan beras tertinggi dicapai pada periode 1981-1990 yang mencapai 101\% dari total pasokan per tahun (masa swasembada). Namun kemudian menurun terus hingga pada tiga tahun terakhir mencapai rata-rata $94 \%$ dari total pasokan per tahun. Lemahnya pasokan beras domestik disebabkan oleh pertumbuhan faktor penentu besarnya produksi beras nasional yang mengalami kecen-derungan menurun dari tahun ke tahun. Faktor tersebut adalah luas lahan panen (harvested area) padi nasional. Selang antara tahun 1999-2005 tercatat dalam data BPS (2006) bahwa telah terjadi pengurangan luas lahan panen padi sebesar 124.204 hektar.

Beras sebagai barang konsumsi sangat dipengaruhi oleh banyak tidaknya orang yang akan mengkonsumsi beras tersebut. Semakin banyak orang yang mengkonsumsi beras maka semakin tinggi pula kebutuhan beras. 
Tabel 1. Konsumsi Beras per Kapita dan Jumlah Penduduk Indonesia 2000-2005

\begin{tabular}{cccc}
\hline Tahun & Penduduk (000 jiwa) & Konsumsi (kg/kapita) & Konsumsi Total (000 ton) \\
\hline 2000 & 211.620 & 133,035 & $28.152,87$ \\
2001 & 215.493 & 133,279 & $28.720,69$ \\
2002 & 219.436 & 133,522 & $29.299,53$ \\
2003 & 223.452 & 133,765 & $29.890,06$ \\
2004 & 227.541 & 134,009 & $30.492,54$ \\
2005 & 231.705 & 134,252 & $31.106,86$ \\
\hline
\end{tabular}

Sumber: Data BPS 2006, diolah (2008).

Informasi tersebut merupakan evaluasi terhadap gambaran masa lalu dan diharapkan tidak terulang lagi di masa yang akan datang. Oleh karena itu diperlukan adanya peramalan yang tepat terhadap produksi dan kebutuhan beras di masa mendatang. Dari perkiraan kebutuhan (konsumsi) dan produksi, diperoleh gambaran ada tidaknya kesenjangan (surplus/defisit), serta besarnya kesenjangan tersebut. Jika hasil analisis menunjukkan bahwa trend konsumsi melebihi produksi beras yang dihasilkan dari dalam negeri, maka harus dirumuskan kebijakan untuk mengatasi persoalan tersebut. Apakah harus melakukan impor beras atau membuka lahan baku untuk produksi yang cukup luas agar produksi padi meningkat secara signifikan, sehingga permintaan dapat terpenuhi. Atau perlu adanya diversifikasi terhadap pangan di masyarakat yang harus dilakukan dengan cepat agar tidak tergantung pada beras. Namun kebijakan impor sendiri dilematis, karena jika terus dilakukan akan terjadi ketergantungan pada impor dan pada gilirannya akan melemahkan tingkat kepastian pangan dan ketahanan pangan nasional, khususnya beras sebagai makanan pokok sebagian besar penduduk Indonesia.

Dari uraian di atas dapat dirumuskan beberapa permasalahan, yaitu: (a) Bagaimana produksi beras nasional tahun 2008-2012? (b) Bagaimana konsumsi beras nasional tahun 20082012 ? (c) Kebijakan apa saja yang telah dilakukan pemerintah dan upaya apa yang dapat dipertimbangkan dalam mengatasi permasalahan perberasan maupun pangan nasional?

\section{TINJAUAN PUSTAKA DAN LANDASAN TEORI}

\section{Tinjauan Pustaka}

\section{Penelitian Terdahulu}

Nuryanti (2005) mengestimasi produksi dan konsumsi beras melalui analisis keseimbangan penawaran (produksi) dan permintaan (konsumsi). Dari hasil penelitian disimpulkan bahwa peningkatan jumlah penduduk dalam jangka panjang sebesar 1 persen menyebabkan peningkatan permintaan beras sebesar 0,82 persen. 
Berbeda dengan Adnyana (2001) yang menerapkan Model Penyesuaian Parsial Nerlove dalam meramalkan produksi dan konsumsi beras nasional. Hasil penelitian menyimpulkan bahwa hasil peramalan areal panen, produktivitas, dan produksi tanaman pangan kurang optimis. Bahkan areal panen padi cenderung menurun dalam 14 tahun ke depan sebesar $-0,013 \%$ per tahun, namun produksi padi cenderung meningkat karena presentase peningkatan produktivitas lebih besar dari penurunan areal panen. Dalam periode yang sama, konsumsi per kapita beras diperkirakan menurun $0,04 \%$ per tahun. Bila tidak ada upaya khusus dalam meningkatkan produksi padi dalam 14 tahun ke depan maka Indonesia diperkirakan akan mengalami peningkatan defisit rata-rata $7,628 \%$ per tahun.

\section{Konsep Dasar Peramalan}

Dalam bidang ekonomi, Clements dan Hendry (2003) menjelaskan bahwa peramalan adalah suatu pernyataan tentang masa depan yang memiliki konsekuensi terhadap kebijakan yang akan dikeluarkan berdasarkan hasil peramalan yang diperoleh. Sedangkan metode peramalan adalah cara memperkirakan secara kuantitatif apa yang akan terjadi pada masa depan, berdasarkan data yang relevan pada masa lalu (Assauri 1984). Mulyono (2000) menjelaskan bahwa peramalan adalah suatu proses memperkirakan secara sistematik tentang apa yang paling mungkin terjadi di masa depan berdasar informasi masa lalu dan sekarang yang dimiliki agar kesalahannya (selisih antara apa yang terjadi dengan hasil perkiraan) dapat diperkecil.

\section{Landasan Teori}

\section{Teori Produksi}

Dalam teori ekonomi standar, penawaran, yang merupakan respon produksi terhadap permintaan, didefinisikan sebagai hubungan fungsional yang menunjukkan berapa banyak suatu komoditas akan ditawarkan pada suatu tempat dan waktu tertentu pada berbagai tingkat harga, faktor lain tidak berubah (Tomek and Robinson, 1981). Sementara produksi sendiri, khususnya produksi komoditi pertanian, lebih diartikan sebagai hubungan fungsional antar beberapa faktor produksi secara fisik, seperti lahan, benih/bibit, pupuk, dan lain sebagainya. Semua faktor saling melengkapi untuk tujuan mendapatkan produksi maksimal.

Adnyana (2001), melalui pendekatan model Penyesuaian Parsial Nerlove, mengatakan bahwa total produksi suatu komoditas pertanian dihitung dari perkalian antara luas areal panen $\left(A_{t}\right)$ dan produktivitasnya $\left(Y_{t}\right)$ (perhitungan ini yang digunakan dalam penelitian) atau dirumuskan sebagai:

$\mathrm{Qg}_{\mathrm{t}}=\mathrm{A}_{\mathrm{t}} \times \mathrm{Y}_{\mathrm{t}}$ 


\section{Teori Konsumsi}

Seperti halnya penawaran, permintaan juga dapat diekspresikan dalam bentuk fungsi matematik, dimana permintaan merupakan fungsi dari berbagai faktor seperti: harga produk tersebut (Pi), harga produk lain (Ps), pendapatan per kapita (In), jumlah penduduk (Pop), permintaan tahun sebelumnya $\left(\mathrm{Qd}_{\mathrm{t}-1}\right)$. Memasukkan volume permintaan tahun sebelumnya ke dalam model respon permintaan berdasarkan suatu asumsi bahwa permintaan tahun sebelumnya mempengaruhi permintaan tahun ini sebagai akibat dari pembentukan kebiasaan atau habits formation (Wohlgenant and Hahn, 1982).

$Q d_{t}=f\left(P i_{t}, P s_{t}, I n_{t}, P o p_{t}, Q d_{t-1}\right)$

Secara matematik, total konsumsi beras juga dapat dirumuskan:

$\mathrm{Qd}=\mathrm{Pop}_{\mathrm{t}} \times \mathrm{Qd}($ perkapita) $\mathrm{t}$

\section{Metode Peramalan Box-Jenkins}

Mulyono (2000) menyebutkan konsep-konsep atau peralatan yang diperlukan dalam penerapan metode Box-Jenkins adalah stasioner, homogen, autocorrelation, dan partial autocorrelation.

a. Stasioner dan Homogen

Kelompok model ARIMA hanya dapat diterapkan pada series yang stasioner. Jika series tidak stasioner, dapat dijadikan stasioner melalui differencing, misalnya first order differencing. Jika dalam proses differencing itu belum diperoleh series yang stasioner, maka second order differencing dapat dicoba. Jika belum stasioner, proses differencing dengan tingkat lebih tinggi tidak perlu dicoba lagi. Secara simbolik bentuknya:

$Z_{t}=\Delta Y_{t}=Y_{t}-Y_{t-1}$

Second order difference adalah:

$\mathrm{W}_{\mathrm{t}}=\Delta \mathrm{Z}_{\mathrm{t}}=\left(\mathrm{Y}_{\mathrm{t}}-\mathrm{Y}_{\mathrm{t}-1}\right)-\left(\mathrm{Y}_{\mathrm{t}-1}-\mathrm{Y}_{\mathrm{t}-2}\right)$

b. Autocorrelation

Koefisien autocorrelation dengan lag $\mathrm{k}$ dirumuskan sebagai:

$\mathrm{r}_{\mathrm{k}}=\frac{\sum_{\mathrm{t}=1}^{\mathrm{n}-\mathrm{k}}\left(\mathrm{Y}_{\mathrm{t}}-\overline{\mathrm{Y}}\right)\left(\mathrm{Y}_{\mathrm{t}+\mathrm{k}}-\overline{\mathrm{Y}}\right)}{\sum_{\mathrm{t}=1}^{\mathrm{n}}\left(\mathrm{Y}_{\mathrm{t}}-\overline{\mathrm{Y}}\right)^{2}}$

..6)

c. Partial Autocorrelation

4 AGRISEP Vol. 8 No. 1 September 2008: 1-18 


$$
\mathrm{r}_{\mathrm{k}}=\frac{\sum_{\mathrm{t}=1}^{\mathrm{n}-\mathrm{k}}\left(\mathrm{Y}_{\mathrm{t}}-\overline{\mathrm{Y}}\right)\left(\mathrm{Y}_{\mathrm{t}+\mathrm{k}}-\overline{\mathrm{Y}}\right)}{\sum_{\mathrm{t}=1}^{\mathrm{n}}\left(\mathrm{Y}_{\mathrm{t}}-\overline{\mathrm{Y}}\right)^{2}}
$$

\section{Kerangka Pemikiran}

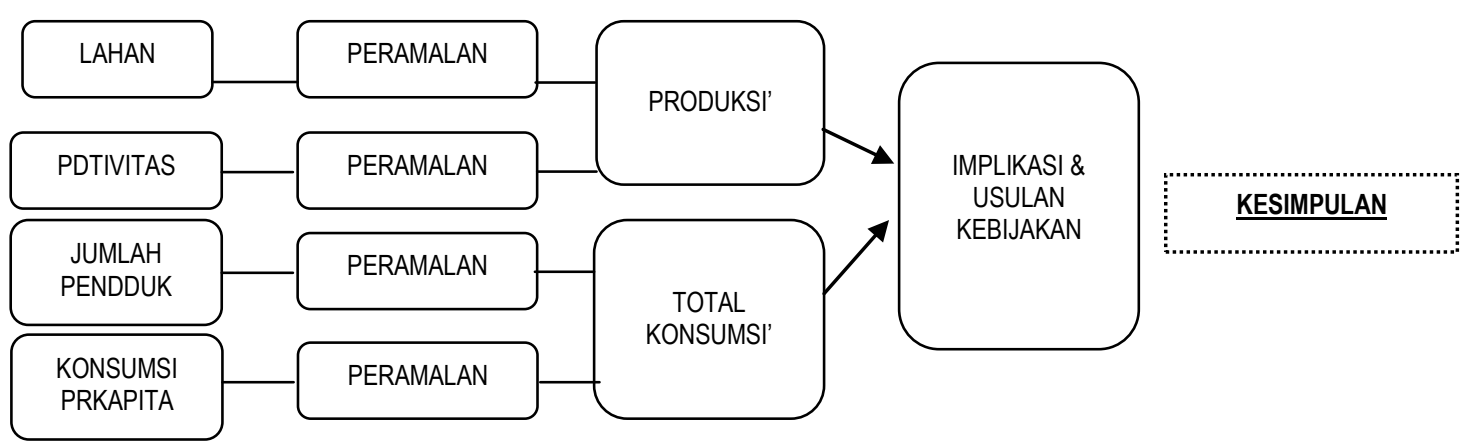

Gambar 1. Skema Kerangka Pemikiran

\section{METODE PENELITIAN}

Data yang digunakan dalam penelitian ini adalah data sekunder yang diperoleh dari Departemen Pertanian RI dan hasil-hasil penelitian terdahulu tentang beras. Data-data yang diperlukan: luas panen, produktivitas, produksi beras, jumlah penduduk, serta konsumsi beras.

Metode analisis yang digunakan adalah teknik analisis peramalan dengan metode Box Jenkins model ARIMA. Selain itu angka peramalan produksi dan konsumsi beras nasional untuk tahun 2008-2012 juga dapat diperoleh melalui rumus pada persamaan (1), (2), dan (3).

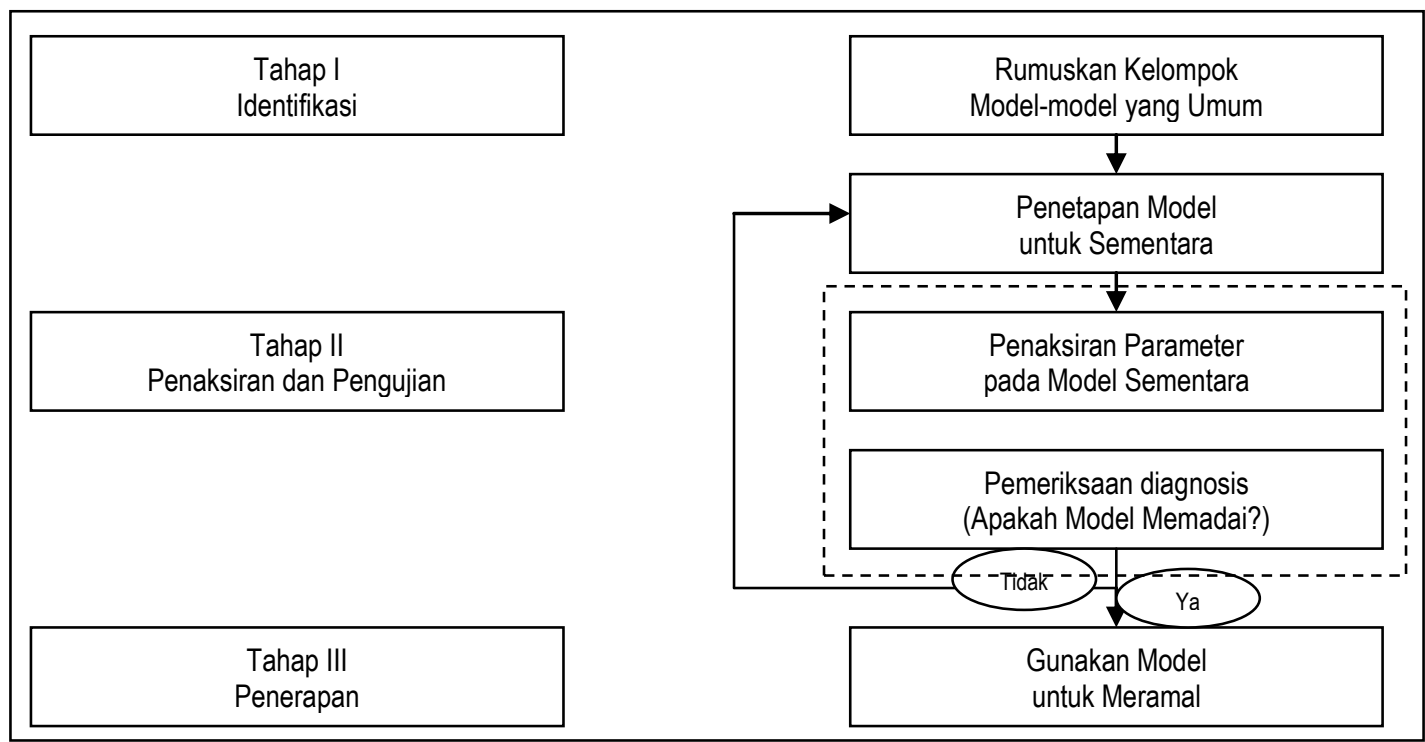


Gambar 2. Skema peramalan pendekatan Box-Jenkins (Makridakis et al, 1999).

Adapun model-model yang sering digunakan dalam metode Box-Jenkins diantaranya:

1. Proses Autoregressive $(P, 0,0)$

$X_{t}=\mu^{\prime}+\Phi_{1} X_{t-1}+\Phi_{2} X_{t-2}+\ldots+\Phi_{p} X_{t-p}+e_{t}$

2. Proses Moving Average $(0,0, q)$

$X_{t}=\mu+e_{t}-\theta_{1} e_{t-1}-\theta_{2} e_{t-2}-\ldots-\theta_{q} e_{t-q}$

3. Proses Autoregressive dan Moving Average, $(p, 0, q)$ atau $(p, d, q)$

$\mathrm{X}_{\mathrm{t}}=\mu^{\prime}+\Phi_{1} \mathrm{X}_{\mathrm{t}-1}+\ldots+\Phi_{\mathrm{p}} \mathrm{X}_{\mathrm{t}-\mathrm{p}}+\mathrm{e}_{\mathrm{t}}-\theta_{1} \mathrm{e}_{\mathrm{t}-1}-\ldots-\theta_{\mathrm{q}} \mathrm{e}_{\mathrm{t}-\mathrm{q}}$

Asumsi yang digunakan dalam penelitian ini adalah adanya pengabaian terhadap faktor koreksi pada faktor-faktor kualitatif.

\section{HASIL ANALISIS DAN PEMBAHASAN}

\section{Prakiraan Luas Lahan Panen Padi, Produksi, dan Konsumsi Beras}

Dalam penentuan model ARIMA $(p, d, q)$, nilai $p, d$, dan $q$ dicari dengan mencoba-coba model sampai nilai masing-masing koefisien regresi pada persamaan ARIMA dianggap signifikan secara statistik (pada penelitian ini menggunakan taraf kepercayaan $95 \%$ atau a adalah $5 \%$ ).

\section{Prakiraan Produksi Beras Nasional}

\section{Prakiraan Luas Lahan Panen Padi Nasional}

Hasil pengamatan series menunjukkan bahwa model yang dianggap tepat adalah model ARIMA $(2,1,0)$ karena semua koefisien parameter signifikan secara statistik (Tabel 2).

Tabel 2. Hasil Analisis Prakiraan Untuk Luas Lahan Panen Nasional

\begin{tabular}{|c|c|c|c|}
\hline Parameter & Koefisien & Standar Error & T-Statistik \\
\hline AR (1) & $-0,530$ & 0,148 & $-3,582$ \\
\hline AR (2) & $-0,629$ & 0,148 & $-4,258$ \\
\hline Konstanta & 118,052 & 21,966 & 5,374 \\
\hline \multicolumn{4}{|c|}{ LUAS LAHAN PANEN PADI NASIONAL 2008 - 2012} \\
\hline Tahun & \multicolumn{3}{|c|}{ Luas (000 Hektar) } \\
\hline 2008 & \multicolumn{3}{|c|}{12241,301} \\
\hline 2009 & \multicolumn{3}{|c|}{12267,722} \\
\hline 2010 & \multicolumn{3}{|c|}{12456,408} \\
\hline 2011 & \multicolumn{3}{|c|}{12594,624} \\
\hline 2012 & \multicolumn{3}{|c|}{12657,562} \\
\hline
\end{tabular}

Sumber: Hasil Olahan Data, 2008. 
Berdasarkan hasil analisis pada Tabel 2, prakiraan mengikuti model ARIMA $(2,1,0)$. Karena mengikuti proses AR, maka Prakiraan luas lahan panen padi periode yang akan datang menggunakan persamaan (10): $X_{t}=118,052-0,530 X_{t-1}-0,629 X_{t-2}+e_{t}$

Pada Tabel 2, AR (1) memiliki koefisien sebesar $-0,530$, artinya bahwa jika luas lahan panen padi nasional pada satu tahun sebelumnya bertambah seluas 1 juta hektar, maka luas lahan panen padi pada saat ini akan berkurang seluas 0,530 hektar. Sementara AR (2) dengan koefisien sebesar - 0,629 menunjukkan bahwa angka luas lahan dua tahun sebelum periode sekarang memberikan pengaruh sebesar nilai tersebut. Nilai negatif pada koefisien mengindikasikan adanya pertumbuhan yang negatif pada luas lahan panen padi nasional dari tahun ke tahun.

Dapat dilihat bahwa angka prakiraan menunjukkan adanya peningkatan luas lahan panen padi sawah secara nasional sampai tahun 2012. Jumlah penambahan luas areal panen diperkirakan sebesar 818 ribu hektar sejak tahun 2005 atau rata-rata 116 ribu hektar setiap tahun, dan pada tahun 2012, pertumbuhan luas lahan panen padi diperkirakan hanya sebesar 0,5 persen. Pertambahan luas lahan panen ini tergolong rawan untuk mencapai target swasembada, karena jumlah lahan yang beralih fungsi ke usaha non-pertanian rata-rata mencapai 110 ribu setiap tahun. Pertumbuhan yang lamban (levelling of) ini tentu saja akan menimbulkan masalah di kemudian hari. Apa yang terjadi di Indonesia sebagai negara agraris sangat berbeda dengan kondisi yang ada di salah satu negara penghasil kopi terbesar di dunia, yaitu Brasil. Brasil memang menjadikan kopi sebagai komoditas utamanya, namun setiap tahun, terjadi peningkatan yang sangat signifikan terhadap penambahan areal budidaya tanaman padi. Dari tahun 1999 sampai 2000 terjadi peningkatan luas areal tanam rata-rata sebesar $110 \%$ untuk setiap jenis benih unggul yang sedang diusahakan di sawah dataran tinggi (Breseghelo et al 2001).

Terlepas dari kondisi yang memprihatinkan tentang pertambahan luas lahan panen padi nasional, hasil prakiraan dengan model ARIMA $(2,1,0)$ dianggap tepat. Hal ini dapat dilihat pada gambar kurva perbandingan nilai aktual dengan nilai prakiraan dibawah ini yang memiliki residual sangat kecil, karena nilai prakiraan menyebar mendekati nilai aktual luas lahan panen padi nasional nasional secara signifikan (t-statistik membuktikan tingkat signifikansinya dengan probability value mendekati nol dibawah 0,05 ). 


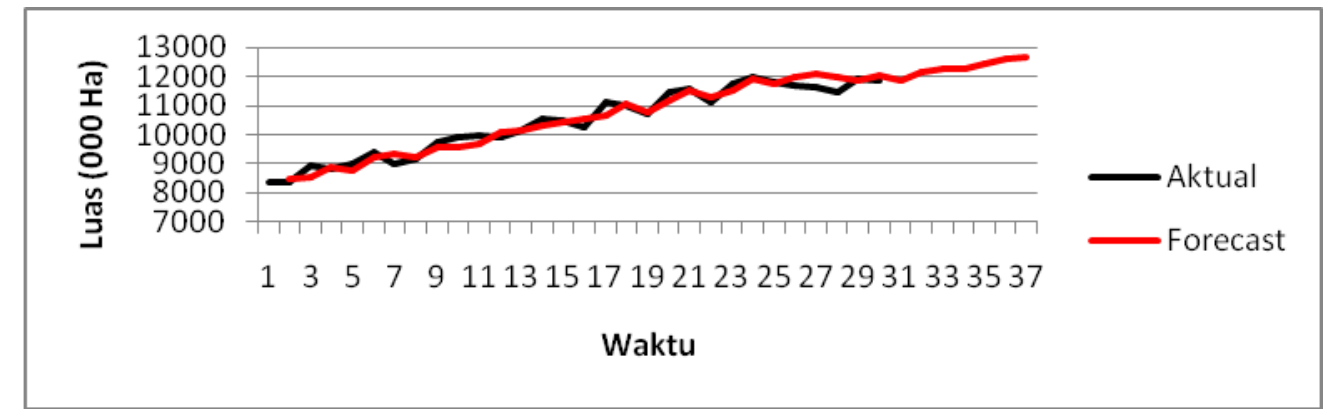

Gambar 3. Kurva Perbandingan Hasil Analisis Nilai Aktual dan Prakiraan Luas Lahan Panen Padi Nasional

\section{Prakiraan Produktivitas Lahan Padi Nasional}

Berdasarkan hasil analisis, prakiraan produktivitas lahan nasional mengikuti model ARIMA $(1,1,0)$. Artinya produktivitas lahan pada tahun yang diramalkan dipengaruhi oleh produktivitas lahan satu tahun sebelumnya, dengan syarat satu pembeda (d).

Dari Tabel 3 dapat dilihat nilai koefisien AR (1) sebesar 0,412, artinya bahwa jika produktivitas satu tahun sebelumnya (t-1) meningkat 1 ton per hektar, maka produktivitas pada tahun ke-t akan bertambah sebesar 0,4067 ton per hektar dengan pertambahan konstanta sebesar 0,033 . Secara statistik angka prakiraan tersebut tepat, karena signifikan pada level kepercayaan 95\% dengan nilai t-hitung sebesar 2,374. Sementara untuk mendapatkan angka prakiraannya, maka persamaan (10) diubah menjadi: $X_{t}=0,033+0,412 X_{t-1}+e_{t}$

Tabel 3. Hasil Analisis Prakiraan Produktivitas Lahan Padi Nasional

\begin{tabular}{cccc}
\hline \multicolumn{1}{c}{ Parameter } & Koefisien & Standar Error & T-Statistik \\
\hline AR (1) & 0,412 & 0,174 & 2,374 \\
Konstanta & 0,033 & 0,018 & 1,909 \\
\hline \multicolumn{5}{c}{ PRODUKTIVITAS LAHAN PADI NASIONAL 2008 - 2012 } \\
\hline Tahun & Produktivitas Lahan (Ton/Ha; telah dikonversi dalam bentuk beras) \\
\hline 2008 & \multicolumn{3}{c}{2,773} \\
2009 & 2,806 & \\
2010 & \multicolumn{3}{c}{2,839} \\
2011 & 2,873 & \\
2012 & 2,906 & \\
\hline
\end{tabular}

Sumber: Hasil Olahan Data, 2008.

Dari hasil analisis produktivitas diperkirakan akan terus meningkat dari tahun ke tahun sampai tahun 2012 dengan rata-rata kenaikan sebesar 0,033 ton beras per hektar setiap tahunnya. Kenaikan produktivitas lahan disebabkan oleh adanya kemajuan dalam bidang teknologi 
pertanian, mulai dari tersedianya benih unggul yang lebih tahan terhadap serangan hama, penyakit balst, tahan kekeringan. Disamping itu perubahan telah terjadi secara perlahan seperti penggunaan pupuk hayati, pestisida organik, serta menerapkan sistem praktek pertanian ramah lingkungan (good agricultural practices).

\section{Prakiraan Produksi Beras Nasional}

Berdasarkan hasil analisis, prakiraan produksi beras nasional mengikuti model ARIMA $(3,1,0)$. Artinya produksi beras pada tahun yang diramalkan dipengaruhi oleh produksi beras tiga tahun sebelumnya, dengan syarat satu pembeda (d). Hasil prakiraan produksi beras nasional tersaji dalam Tabel 4.

Tabel 4. Hasil Analisis Prakiraan untuk Produksi Beras Nasional

\begin{tabular}{cccrr}
\hline Parameter & Koefisien & Standar Error & T-Statistik \\
\hline AR (1) & 0,0877 & 0,1817 & 0,4825 \\
AR (2) & $-0,3209$ & 0,1694 & $-1,8949$ \\
AR (3) & 0,4067 & 0,1801 & 2,2579 \\
Konstanta & 597,5522 & 186,5714 & 3,2028 \\
\hline \multicolumn{5}{c}{ PRODUKSI BERAS NASIONAL 2008-2012 (000 Ton) } \\
\hline Tahun & Batas Pesimis & Mean' & Batas Optimis \\
\hline 2008 & $30.415,252$ & $33.484,291$ & $36.553,330$ \\
2009 & $30.070,360$ & $33.826,472$ & $37.582,584$ \\
2010 & $30.059,244$ & $34.584,185$ & $39.109,125$ \\
2011 & $30.214,928$ & $35.239,123$ & $40.263,318$ \\
2012 & $30.135,183$ & $35.686,446$ & $41.237,709$ \\
\hline
\end{tabular}

Sumber: Hasil Olahan Data, 2008.

Dari Tabel 4 dapat dilihat nilai koefisien AR (3) sebesar 0,4067, artinya bahwa jika produksi tiga tahun sebelumnya (t-3) meningkat 1 juta ton, maka produksi pada tahun ke-t akan bertambah sebesar 0,4067 juta ton. Secara statistik angka ramalan tersebut tepat, karena signifikan pada lever kepercayaan 95\%. Sementara salah satu nilai koefisien, yaitu AR (1), tidak signifikan pada taraf kepercayaan yang sama (t-stat $=0,4825)$. Ini didapat karena setelah dilakukan pengujian model berulang-ulang untuk menentukan model yang tepat, khususnya untuk pola ARIMA $(p, 1,0)$, hasil terbaik dengan signifikansi lebih baik dan error terkecil adalah dengan nilai $p=3$ atau mengikuti pola ARIMA $(3,1,0)$. Ini merupakan salah satu kelemahan dari model prakiraan karena semua model estimasi didapat melalui proses coba-coba untuk mencari yang terbaik. Sementara untuk mendapatkan angka ramalannya, maka persamaan (11) diubah menjadi:

$$
X_{t}=579,5522+0,0877 X_{t-1}-0,3209 X_{t-2}+0,4067 X_{t-3}+e_{t}
$$


Jika dilihat dari analisis perbandingan nilai aktual dan nilai ramalan memiliki sebaran data yang hampir sama, artinya residual antara keduanya sangat kecil (Gambar 4). Meskipun demikian, dapat dilihat bahwa interval antara batas pesimis dan optimis juga relatif besar. Dalam kasus ini, metode Box-Jenkins dengan model ARIMA $(3,1,0)$ dianggap tepat dalam meramalkan produksi beras nasional tahun 2008-2012.

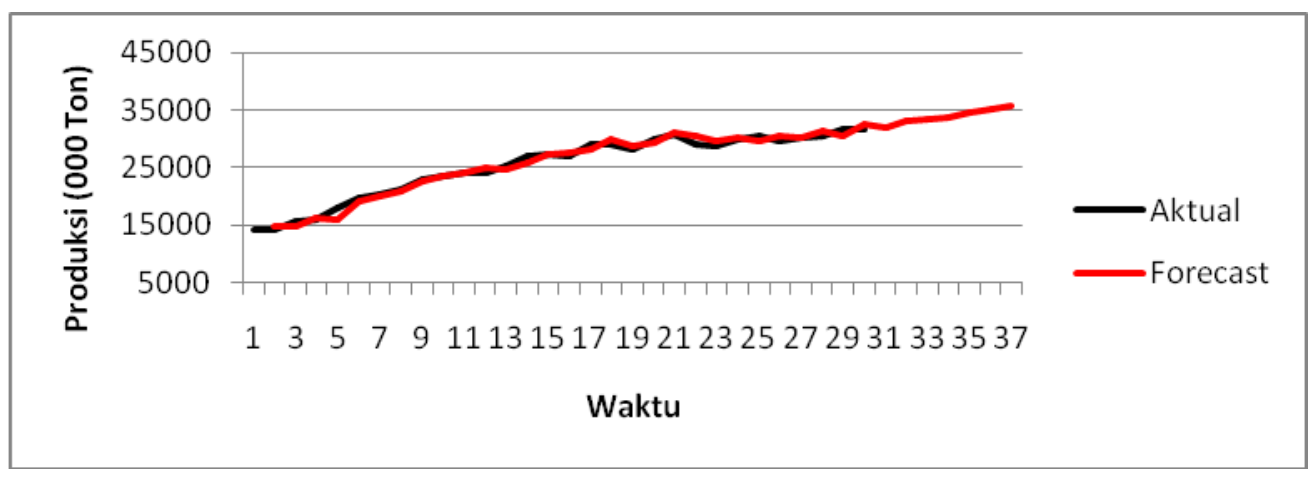

Gambar 4. Kurva Perbandingan Hasil Analisis Nilai Aktual dan Ramalan Produksi Beras Nasional

Tabel 5. Hasil Prakiraan Produksi Beras Nasional Tahun 2008-2012

\begin{tabular}{cccccc}
\hline Tahun & $\begin{array}{c}\text { Luas Panen } \\
\text { (ARAM) }\end{array}$ & $\begin{array}{c}\text { Produktivitas } \\
\text { (ARAM) }\end{array}$ & $\begin{array}{c}\text { Batas } \\
\text { Pesimis }\end{array}$ & $\begin{array}{c}\text { Produksi' } \\
\text { (000 Ton) }\end{array}$ & $\begin{array}{c}\text { Batas } \\
\text { Optimis }\end{array}$ \\
\hline 2008 & $12.241,301$ & 2,773 & $28.971,33$ & $33.945,127$ & $39.243,32$ \\
2009 & $12.267,722$ & 2,806 & $28.367,67$ & $34.423,227$ & $40.956,46$ \\
2010 & $12.456,408$ & 2,839 & $28.295,08$ & $35.363,742$ & $43.075,33$ \\
2011 & $12.594,624$ & 2,873 & $28.287,98$ & $36.184,354$ & $44.822,48$ \\
2012 & $12.657,562$ & 2,906 & $28.070,62$ & $36.782,875$ & $46.392,63$ \\
\hline
\end{tabular}

Sumber: Hasil Olahan Data, 2008.

Dari Tabel 5 dapat kita lihat bahwa pada tahun 2008 diperkirakan dengan lahan panen seluas 12241,301 ribu hektar dan produktivitas lahan mencapai 2,773 ton beras per hektar, maka produksi beras yang dihasilkan secara nasional adalah sebesar 33945,127 ribu ton atau hampir 34 juta ton. Terjadi peningkatan sebesar 2,2 juta ton sejak tahun 2005. Kemudian meningkat lagi menjadi 36,7 juta ton pada tahun 2012 dengan rata-rata kenaikan produksi sebesar 709.437 ton per tahun. Kenaikan tertinggi dicapai pada tahun 2010 yaitu sebesar 940.515 ton, hampir mendekati angka 1 juta ton.

Jika dibandingkan hasil dari kedua metode prakiraan di atas, hasil prakiraan menunjukkan gejala yang sama dengan angka yang hampir sama pula. Namun hasil dari metode yang kedua dianggap lebih baik karena uji signifikansi model pada luas lahan panen dan produktivitas menunjukkan bahwa t-statistik lebih besar dari t-tabel. Sementara untuk prakiraan produksi 
dengan model ARIMA $(3,1,0)$ menunjukkan bahwa salah satu parameter AR (1) tidak signifikan. Sehingga prakiraan produksi beras yang dibahas adalah hasil prakiraan produksi dengan menggunakan angka prakiraan luas lahan dan produktivitas.

\section{Prakiraan Konsumsi Beras Nasional}

Dalam memprakirakan konsumsi beras nasional dilakukan dengan mengalikan angka prakiraan jumlah penduduk dengan konsumsi perkapita.

\section{Prakiraan Jumlah Penduduk Nasional}

Hasil pengamatan series menunjukkan bahwa model yang dianggap tepat adalah model $\operatorname{ARIMA}(0,1,1)$.

Tabel 6. Hasil Analisis Prakiraan Jumlah Penduduk Nasional

\begin{tabular}{crrr}
\hline \multicolumn{1}{c}{ Parameter } & Koefisien & Standar Error & T-Statistik \\
\hline AR (1) & 0,445 & 0,182 & 2,441 \\
Konstanta & 3419,767 & 160,402 & 21,320 \\
\hline \multicolumn{4}{c}{ JUMLAH PENDUDUK NASIONAL 2008 - 2012 } \\
\hline Tahun & Jumlah Penduduk (000 jiwa) & \\
\hline 2008 & 241388,523 \\
2009 & 244808,290 & \\
2010 & 248228,057 & \\
2012 & 251647,825 & \\
\hline
\end{tabular}

Sumber: Hasil Olahan Data, 2008.

Hasil prakiraan menunjukkan bahwa terjadi peningkatan jumlah penduduk dari ke tahun. Pada tahun 2008 diperkirakan penduduk Indonesia mencapai 241 juta jiwa lebih dan terus meningkat sampai lebih dari 255 juta jiwa pada tahun 2012, atau bertambah lebih kurang sebesar 14 juta jiwa. Bertam-bahnya penduduk pasti akan meningkatkan kebutuhan akan pangan nasional terutama beras. Hal itu akan berlaku jika belum terjadi konversi pangan besar-besaran secara nasional. Namun jika pola makan perorang menunjukkan penurunan terhadap konsumsi beras, maka bukan tidak mungkin total konsumsi beras nasional juga akan turun.

Tingginya pertumbuhan pendu-duk diperkirakan karena program KB yang dulu dianggap berhasil menurunkan angka laju pertumbuhan penduduk, kini tidak lagi begitu diperhatikan. Fokus lebih kepada bagaimana menyediakan pangan bagi orang-orang yang terus bertambah dan tidak berfikir untuk memperhatikan bagaimana mengantisipasi pertam-bahan jumlah orang yang akan mengkonsumsi pangan tersebut. Padahal jika ada kontrol terhadap pertambahan jumlah penduduk, maka konsumsi beras dengan sendirinya akan lebih mudah untuk dikendalikan. 


\section{Prakiraan Konsumsi Beras Per Kapita Nasional}

Hasil pengamatan series menunjukkan bahwa model yang dianggap tepat adalah model ARIMA $(2,0,0)$, artinya bahwa konsumsi beras per kapita nasional dipengaruhi oleh konsumsi beras per kapita dua tahun sebelumnya tanpa pembeda.

Tabel 7. Hasil Analisis Prakiraan Konsumsi Beras Per Kapita Nasional

\begin{tabular}{|c|c|c|c|}
\hline Parameter & Koefisien & Standar Error & T-Statistik \\
\hline AR (1) & 1,194 & 0,174 & 6,871 \\
\hline $\operatorname{AR}(2)$ & $-0,386$ & 0,173 & $-2,223$ \\
\hline Konstanta & 130,455 & 1,557 & 83,780 \\
\hline \multicolumn{4}{|c|}{ KONSUMSI BERAS PER KAPITA NASIONAL 2008 - 2012} \\
\hline Tahun & \multicolumn{2}{|c|}{ Konsumsi (Kg/Kapita) } & \\
\hline 2008 & \multicolumn{2}{|r|}{131,994} & \\
\hline 2009 & \multicolumn{2}{|r|}{131,401} & \\
\hline 2010 & \multicolumn{2}{|r|}{130,990} & \\
\hline 2011 & \multicolumn{2}{|r|}{130,729} & \\
\hline 2012 & \multicolumn{2}{|r|}{130,576} & \\
\hline
\end{tabular}

Sumber: Hasil Olahan Data, 2008.

Tabel 7 menunjukkan bahwa semua koefisien model signifikan, sehingga dapat dikatakan bahwa model ARIMA adalah tepat. Dari hasil analisis juga didapat koefisien AR (1) sebesar 1,194 (positif) dan koefisien AR (2) -0,386 (negatif). Ini menunjukkan bahwa konsumsi pada satu tahun sebelum tahun $t$ berpengaruh positif terhadap konsumsi beras per kapita tahun $t$, sedangkan konsumsi beras per kapita pada tahun $\mathrm{t}-2$ berpengaruh negatif. Ini berarti jika konsumsi dua tahun lalu naik sebesar $1 \mathrm{~kg}$ per kapita, maka pada tahun ini konsumsi beras akan turun sebesar 0,386 kg per kapita. Berdasarkan uji t (95\%), angka ini signifikan secara statistik. Adanya hubungan antara konsumsi beras per kapita tahun sebelumnya dengan saat ini adalah sebagi akibat dari pembentukan kebiasaan atau habits formation. Sementara untuk mengetahui angka prakiraan seperti yang terlihat pada tabel 7 , terlebih dahulu harus mengubah persamaan (10) menjadi:

$$
X_{t}=130,455+1,194 X_{t-1}-0,386 X_{t-2}+e_{t}
$$

Hasil analisis menunjukkan bahwa terjadi penurunan konsumsi beras setiap tahunnya. Pada tahun 2005 konsumsi beras per kapita nasional mencapai $134 \mathrm{~kg}$ per kapita. Nilai ini lebih tinggi dibandingkan tahun 2012 yang diperkirakan hanya sebesar 130,576 kg per kapita. Ini memberikan signal positif ketika pemerintah gencar-gencarnya berdiskusi tentang masalah perberasan nasional. Gejala yang terjadi (sesuai dengan angka prakiraan) menggambarkan kondisi dimana masyarakat mulai berfikir untuk mengurangi konsumsi beras mereka karena faktor kemampuan dalam mengkonsumsi produk lain sebagai sumber energi selain beras. Hal ini 
sebaiknya dijadikan sinyalemen positif oleh pemerintah untuk lebih menggalakkan program diversifikasi pangan substitusi.

\section{Prakiraan Konsumsi Beras Nasional}

Prakiraan konsumsi beras nasional dicobakan pada dua metode yang berbeda dengan teknik dasar yang sama. Metode pertama yang digunakan adalah penerapan model ARIMA BoxJenkins secara langsung. Sementara pada metode kedua, metode Box-Jenkins diaplikasikan untuk meramalkan jumlah penduduk dan konsumsi per kapita terlebih dahulu, kemudian hasil prakiraan kedua variabel tersebut digunakan untuk meramalkan konsumsi beras nasional.

Hasil uji menunjukkan bahwa data mengikuti model ARIMA $p=2, d=2$, dan $q=0$, atau disimbolkan sebagai ARIMA (2,2,0). Artinya bahwa konsumsi beras nasional yang akan diramalkan dipengaruhi oleh data konsumsi beras nasional dua tahun sebelumnya.

Tabel 8. Hasil Analisis Prakiraan untuk Konsumsi Beras Nasional

\begin{tabular}{cccc}
\hline \multicolumn{1}{c}{ Parameter } & Koefisien & Standar Error & T-Statistik \\
\hline AR (1) & $-0,3213$ & 0,1727 & $-1,8608$ \\
AR (2) & $-0,5675$ & 0,1935 & $-2,9335$ \\
Konstanta & $-28,9038$ & 26,5805 & $-1,0874$ \\
\hline \multicolumn{5}{c}{ Kahun } & Batas Pesimis & Mean' & Batas Optimis \\
\hline 2008 & $21.692,727$ & $23.215,010$ & $24.737,294$ \\
2009 & $20.779,204$ & $22.853,384$ & $24.927,564$ \\
2010 & $19.576,358$ & $22.346,081$ & $25.115,804$ \\
2011 & $18.396,798$ & $21.899,984$ & $25.403,169$ \\
2012 & $17.184,329$ & $21.462,304$ & $25.740,280$ \\
\hline
\end{tabular}

Sumber: Hasil Olahan Data, 2008.

Tabel 8 menunjukkan bahwa ada 2 koefisien model yaitu AR (1) dan konstanta yang tidak signifikan. Namun perlu diketahui bersama bahwa ini merupakan nilai terbaik yang didapat setelah dilakukan percobaan berbagai model. Secara statistik model ARIMA $(2,2,0)$ memiliki nilai error terkecil, t-statistik yang lebih baik, serta sebaran nilai probability hampir seluruhnya mendekati nol atau lebih kecil dari 0,05 dengan sifat tersebar secara random. Hanya $\operatorname{lag} 1, \operatorname{lag} 5$, lag 6 , dan $\operatorname{lag} 7$ saja yang lebih besar dari 0,05 atau signifikan berbeda dari nol. Angka koefisien AR (2) sebesar 0,5675 berarti jika konsumsi dua tahun lalu naik sebesar 1 juta ton, maka pada tahun ini konsumsi beras akan turun sebesar 0,5675 juta ton atau 567,5 ribu ton. Sementara untuk mengetahui angka ramalan, terlebih dahulu harus mengubah persamaan (10) menjadi: 


$$
X_{t}=-28,9038-0,3213 X_{t-1}-0,5676 X_{t-2}+e_{t}
$$

Total konsumsi beras nasional merupakan agregat dari konsumsi beras individu. Oleh karena itu prakiraan konsumsi beras dapat dilakukan dengan metode lain, tidak hanya dengan teknik prakiraan, melainkan dapat diperoleh dari hasil analasis prakiraan terhadap turunannya, yaitu jumlah penduduk sebagai individu dan konsumsi per kapita. Hasil prakiraan konsumsi beras nasional dapat dilihat pada Tabel 9.

Tabel. 9. Hasil Prakiraan Konsumsi Beras Nasional Tahun 2008-2012

\begin{tabular}{cccccc}
\hline Tahun & $\begin{array}{c}\text { Jumlah } \\
\text { Penduduk } \\
\text { (ARAM) }\end{array}$ & $\begin{array}{c}\text { Konsumsi Per } \\
\text { Kapita } \\
\text { (ARAM) }\end{array}$ & $\begin{array}{c}\text { Batas } \\
\text { Pesimis }\end{array}$ & $\begin{array}{c}\text { Konsumsi } \\
\text { Total } \\
\text { (000 Ton) }\end{array}$ & $\begin{array}{c}\text { Batas } \\
\text { Optimis }\end{array}$ \\
\hline 2008 & $241.388,523$ & 131,994 & $29.650,731$ & $31.861,836$ & $34.130,802$ \\
2009 & $244.808,290$ & 131,401 & $29.716,492$ & $32.168,054$ & $34.689,979$ \\
2010 & $248.228,057$ & 130,990 & $29.904,107$ & $32.515,393$ & $35.207,543$ \\
2011 & $251.647,825$ & 130,729 & $30.169,688$ & $32.897,668$ & $35.714,929$ \\
2012 & $255.067,592$ & 130,576 & $30.482,914$ & $33.305,705$ & $36.224,993$ \\
\hline
\end{tabular}

Sumber: Hasil Olahan Data, 2008.

Hasil kedua metode menunjukkan trend yang berbeda. Metode pertama konsumsi total diperkirakan mengalami penurunan, sedangkan metode kedua konsumsi total cenderung meningkat. Meskipun jika dilihat dari interval batas pesimis dan optimis, metode pertama memiliki range yang lebih sempit, namun hasil ramalan kurang mencerminkan keadaan yang sebenarnya. Hal ini dikarenakan jumlah penduduk tidak begitu diperhatikan. Padahal jumlah penduduk memegang peranan yang cukup besar dalam menentukan jumlah beras yang akan dikonsumsi. Sehingga metode yang kedua dianggap lebih tepat. Disamping itu, hasil metode pertama parameter AR (1) tidak signifikan pada level alpha 0,05. Sedangkan untuk peramalan metode kedua, semua koefisien parameter signifikan pada taraf kepercayaan $95 \%$.

Dari tabel 9 dapat dilihat bahwa konsumsi beras nasional secara total cenderung meningkat, meskipun keadaan konsumsi beras per kapita cenderung menurun setiap tahunnya mulai tahun 2008-2012. Jika dilihat dari segi pola makan terhadap beras secara individu telah terjadi pergeseran ke konsumsi bukan beras. Namun secara agregat konsumsi terus bertambah karena pertambahan jumlah penduduk. Berarti yang menjadi permasalahan sebenarnya adalah tingginya pertumbuhan penduduk.

Implikasi Kebijakan

Dasar Pemikiran

14 AGRISEP Vol. 8 No. 1 September 2008: 1-18 
Berbasis pada kebijakan pembangunan sektor pertanian dan ketahanan pangan, maka pemecahan masalah di subsektor pangan, khususnya beras, dapat ditempuh melalui pengembangan tanaman pangan dan konsumsi pangan lokal serta penganekaragaman konsumsi pangan yang mengarah pada perbaikan konsumsi pangan oleh masyarakat, baik dari segi jumlah maupun kualitas makanan termasuk keragaman dalam rangka mewujudkan konsumsi pangan dengan gizi seimbang. Dengan terpenuhinya konsumsi pangan yang beragam dari waktu ke waktu pada masa yang akan datang, maka masyarakat dapat hidup sehat dan mampu melaksanakan aktifitasnya sehari-hari secara produktif, sehingga diharapkan mampu meningkatkan kesejahteraan. Untuk mencapai kondisi yang demikian, diperlukan beberapa faktor utama dalam pengambangan subsektor pangan, khususnya konsumsi pangan, yaitu:

1. Ketersediaan pangan

a. Kecukupan Pangan dalam Jumlah

Untuk memenuhi variabel ini, maka peningkatan kapasitas produksi melalui terobosan teknologi sangat mutlak diperlukan. Oleh karena itu, pengembangan sistem ilmu pengetahuan dan teknologi harus dilakukan demi mendorong penggunaan input yang makin seimbang, perbaikan sistem pascapanen untuk mengurangi loss yang masih cukup tinggi, serta perbaikan kualitas produksi melalui subsidi benih unggul (Hardono et al 2004). Selain cara diatas, untuk meningkatkan kemampuan produksi beras nasional perlu dilakukan pemeliharaan kapasitas sumberdaya lahan dan perairan, perluasan lahan baku untuk produksi, serta peningkatan intensitas tanam, serta sistem distribusi pangan yang mencakup tercapainya stabilitas harga pangan antar waktu dan antar wilayah.

Disamping itu pemenuhan jumlah pangan yang cukup dapat ditempuh melalui impor pangan, khususnya beras. Ini merupakan cara yang paling tidak dianjurkan, karena mengancam kemandirian pangan dan rentan penyimpangan. Soepanto (1997) menjelaskan ada fenomena yang menunjukkan bahwa pengadaan dalam negeri pada tahun tersebut semakin sulit diandalkan untuk memupuk stok penyangga yang diperlukan untuk stabilisasi. Tingkat pertumbuhan produksi beras rata-rata tahunan yang semakin mengecil sejak Pelita IV, banyak mempengaruhi semakin kecilnya pengadaan beras daam negeri. Sejak mengalami kenaikan tertinggi rata-rata tahunan pada Pelita III sebesar 6,58\% per tahun (perbedaan sangat signifikan karena saat ini pertumbuhan hanya $1,57 \%$ per tahun), kemudian terus menurun menjadi $3,42 \%$ per tahun pada Pelita IV dan $3,01 \%$ pada Pelita V. Demikian juga pada Pelita VI yang mengalami penurunan yaitu menjadi $2,34 \%$ per tahun. Akibatnya pengadaan yang dapat diserap dari dalam negeri juga terus turun dari 
rata-rata 6,4\% per tahun pada Pelita III menjadi 3,3\% per tahun pada Pelita VI. Fenomena ini mengakibatkan upaya pengendalian harga beras di dalam negeri semakin mengarah kepada impor beras sebagai komponen utama untuk pemupukan stok pengangga menjadi tidak terelakkan. Dengan adanya impor tersebut diharapkan akan tersedia stok yang cukup di dalam negeri yang memungkinkan pemerintah melakukan pengendalian harga setia saat. Kebijakan ini akhirnya dapat mengatasi masalah kelangkaan beras di pasar dan harga beras tetap stabil serta dapat djangkau oleh penduduk, sehingga kebutuhan pangan mereka dapat terpenuhi.

Namun jika dilihat dari hasil penelitian ini, antara angka prakiraan produksi dengan angka prakiraan konsumsi terdapat residual yang cukup besar. Dengan kondisi seperti ini pemerintah masih dapat melakukan banyak hal dalam mengatasi masalah penyediaan pangan. Hasil prakiraan menunjukkan bahwa ada residual lebih dari 2 juta ton beras. Jumlah ini tentu saja dapat dijadikan stok penyangga, bahkan pemerintah bisa melakukan ekspor beras. Wacana ekspor beras sebaiknya mulai dipertimbangkan demi meningkatkan gairah petani agar lebih produktif lagi. b. Kecukupan Kualitas, Keragaman, dan Keamanan Pangan

Di sisi lain jenis pangan yang dikonsumsi harus mampu memenuhi kebutuhan kalori, protein, vitamin, dan mineral. Oleh karena itu perlu dilakukan upaya penggalakan program diversifikasi pangan dengan pemanfaatan pangan sumber kalori, protein, vitamin, dan mineral yang dapat diproduksi secara lokal. Faktor keamanan pangan juga harus terjamin, karena makanan berhubungan dengan kesehatan seseorang, maka tidak boleh mengandung bahanbahan yang dapat membahayakan kesehatan orang yang akan mengkonsumsi makanan tersebut.

\section{Industri Pangan}

Pengembangan teknologi pengolahan untuk meningkatkan daya tarik ekonomis dan fisik dari berbagai bahan pangan lokal/tradisional non beras yang difasilitasi oleh lembaga-lembaga pemerintah dan swasta merupakan cara lain dalam meningkatkan kemampuan penyediaan pangan bagi penduduk.

\section{Daya Beli}

Daya beli dimaksudkan sebagai jaminan terhadap produk pangan, beras maupun lainnya, ada di pasar dengan harga yang terjangkau sehingga penduduk mampu memenuhi kebutuhan akan pangan sesuai dengan kemampuan daya belinya. Simatupang et al (1997) mengatakan bahwa ada hubungan yang kuat antara tingkat pendapatan dengan preferensi terhadap makanan.

4. Kesadaran 
Di sisi lain jenis pangan yang dikonsumsi ditentukan oleh adanya kesadaran pangan dan gizi dari berbagai lapisan masyarakat yang dipengaruhi oleh beberapa faktor, yaitu pengetahuan mengenai pangan dan gizi, kebiasaan makan dan nilai sosial budaya masyarakat.

\section{Kebijakan Pengembangan Konsumsi Pangan (Tinjauan Umum)}

1. Pemberdayaan Masyarakat

Untuk merubah pola konsumsi pangan masyarakat yang bertumpu pada pangan pokok beras dengan memperhatikan pola konsumsi wilayah setempat, membutuhkan waktu yang cukup lama bagi masyarakat untuk mengenal dan mencoba memperbaiki pola konsumsi pangannya. Oleh karena itu perlu dikembangkan kegiatan-kegiatan yang berbasis masyarakat dengan bentuk kegiatan berkelompok terutama pada wilayah-wilayah miskin serta rawan pangan melalui program pembinaan dan fasilitasi.

2. Peningkatan Kemitraan

Peningkatan kemitraan merupakan implementasi dari koordinasi dan kerjasama riil antara petani dan pemerintah, LSM, Swasta, Lembaga Penelitian, serta Perguruan Tinggi dalam mengembangkan konsumsi pangan terutama tingkat rumah tangga. Kemitraan diarahkan pada kegiatan-kegiatan yang sifatnya dapat meningkatkan produksi, mengolah hasil panen, mengembangkan usaha.

3. Sosialisasi Pengembangan

Untuk memasyarakatkan kebijakan pengembangan ini kepada semua pihak yang mempunyai kepentingan (stakeholders), perlu diadakan sosialisasi secara bertahap dan bertingkat, mulai dari tingkat pusat hingga tingkat lapangan dan didasarkan pada cara-cara yang tidak melanggar norma atau aturan yang berlaku di masyarakat.

\section{KESIMPULAN DAN SARAN}

Dari hasil penelitian dapat disimpulkan:

1. Metode ARIMA dengan turunan luas lahan dan produktivitas, dinilai lebih baik dalam meramalkan produksi. Hasil Prakiraan produksi beras tahun 2008-2012 menunjukkan gejala terus meningkat sepanjang tahun.

2. Metode ARIMA dengan turunan jumlah penduduk dan konsumsi beras perkapita dinilai lebih baik dalam meramalkan kebutuhan beras, karena secara statistik seluruh koefisien parameternya signifikan. Hasil Prakiraan konsumsi beras nasional tahun 2008-2012 menunjukkan kecenderungan yang terus meningkat setiap tahun. 
3. Berdasarkan hasil Prakiraan, kebijakan impor beras tidak tepat lagi jika diambil sebagai alternatif penyediaan pangan penduduk Indonesia. Strategi kebijakan lain yang dapat ditawarkan adalah: (1) diversifikasi pola konsumsi pangan masyarakat; (2) peningkatan kemitraan petani; dan (3) sosialisasi tentang rencana pengembangan konsumsi pangan mulai dari pusat sampai pada level unit lapangan.

Berdasarkan hasil peramalan di atas, maka sebaiknya pemerintah mulai membuka wacana ekspor beras dan mulai diatur untuk dilaksanakan demi merangsang pertumbuhan produksi beras yang lebih baik.

\section{DAFTAR PUSTAKA}

Adnyana MO. 2001. Penerapan Model Penyesuaian Parsial Nerlove Dalam Proyeksi Produksi Dan Konsumsi Beras. Pusat Penelitian dan Pengembangan Tanaman Pangan. Bogor.

[Deptan]. 2006. Neraca Bahan Makanan Indonesia 2004-2005. Badan Ketahanan Pangan Departemen Pertanian. Jakarta.

[BPS]. 2006. Perkembangan Konsumsi Pangan Penduduk Indonesia 1993-2005. BPS. Jakarta.

Arsyad L. 2001. Peramalan Bisnis. BPFE. Yogyakarta.

Assauri S. 1984. Teknik dan Metoda Peramalan; Penerapannya dalam Ekonomi dan Dunia Usaha. Edisi Satu. LPFE. Universitas Indonesia. Jakarta.

Breseghello F dan Guimarães P. 2001. Yield Potential Of Brazillian Upland Rice. IRRN 26.1 Journal. Philipine.

Darwanto, H. Dwidjono dan Prima, Y. R. 2007, Kesejanteraan Petani dan Peningkatan Ketersediaan Pangan: Sebuah Dilemma. Jurnal Ekonomi Rakyat. www.jurnalekonomirakyat.com. (23 Desember 2007)

Hardono SG, Handewi PSR, dan Sri HS. 2004. Liberasi Perdagangan: Sisi Teoritik, Dampak Empiris, dan Perspektif Ketahanan Pangan. Forum Penelitian Agro Ekonomi. h. 75-88.

Clements MP and Hendry FD. 2003. Economic Forecasting: Some Lessons From Recent Research. Economic Modelling 20. Elsevier Journal. h. 301-329.

Makridakis S, Wheelright SC, Gee MC. 1999. Metode dan Aplikasi Peramalan. Binarupa Aksara. Jakarta.

Mulyono, Sri. 2000. Peramalan Bisnis dan Ekonometrika. BPFE. Yogyakarta.

Nuryanti, Sri, 2005. Analisa Keseimbangan Sistem Penawaran dan Permintaan Beras Di Indonesia. Jurnal Agro Ekonomi (1). 71-81. Bogor.

Simatupang P dan Ariani M. 1997. Hubungan Antara Pendapatan Rumah Tangga dan Pergeseran Preferensi Terhadap Pangan. Jurnal Pangan (33). h. 20-29.

Soepanto A. 1997. Perdagangan Bebas dan Skenario Pengendalian Harga Pangan Setelah 2020. Jurnal Pangan (31). 50 - 59.

Tomek WG dan Robinson KL. 1981. Agricultural Product Prices. Second Edition. Cornell University Press. Ithaca and London. 
Wohlgenant M.K dan Hahn WF. 1982. Dynamic Adjustment in Monthly Consumer Demand for Meats. American Journal of Agricultural Economics (AJAE). 
